\title{
Strategies Employed by Grassroots Organizations in Anchoring Community Peace and Cohesion in Kibra Informal Urban Settlements in Nairobi, Kenya
}

\author{
Christine JumaAgaya*, Godfrey Ungaya, Emily Okuto \\ Kisii University, Kenya
}

*Corresponding Author: Christine JumaAgaya, Kisii University, Kenya

\begin{abstract}
Informal settlements have proliferated large cities especially in the developing countries due to the inflow of people as they seek opportunities for their survival. Many support network groups in form of grassroots organizations have cropped up in informal settlements to help alleviate the social and economic life of this population. Various researches carried out in Kibra informal settlement have revealed that grassroots organizations have been at the forefront in trying to create peace and cohesion. However, not much has been done in these studies in terms of investigating the efficacy of the strategies used by the grassroots organizations in fostering sustainable peace and cohesion in Kibra informal settlement. The studyestablished that the principal strategies used to entrench intercommunity peace and cohesion were sports and art, cultural exchanges and collective intergroup programmes such as environmental protection. The findings further revealed that intergroup contacthad transformed funeral welfare groups and self-help groups from tribal enclaves into inclusive units. Despite these milestones, the study noted thatgrassroots organizations lacked proper collaboration mechanisms anchored in law and policy to support community peace and cohesion. The study recommends that government agencies need to collaboratively work with grassroots organizations to enhance local ownership and sustainability of the peace and cohesion programs instituted.
\end{abstract}

Key words: Strategies, Grassroots organisations, community peace, cohesion and Kenya

\section{INTRODUCTION}

In African communities, grassroots peace-building and social cohesion programs have a long history. Nevertheless, within "mainstream" peacebuilding discourses and practices, it was the post-Cold War local orientation in peacebuilding, expressed in the idea of peacebuilding from below, that gave greater prominence to these initiatives (Nganje, 2021).Lederach(1997) sees peace-building as "a comprehensive concept that encompasses, produces and maintains the full range of processes, strategies and phases necessary to transform conflict into more sustainable, peaceful relations" (p. 20). Peacebuilding is a complex, long-term process that aims to resolve relationship, institutional and social problems across a wide variety of processes that co-create a peace infrastructure (Lederach, 1997, p. 22).

Most dispute resolution and peacebuilding programs rely on the efforts of the government or top-level leadership. Peace initiatives, however, involve a systematic approach which is conducted simultaneously at the level of the grass roots. Because of their commitment to the development of permanent peace, the restoration of social conditions, the enforcement of peace negotiations, the propagation of peace issues, the establishment of a culture of peace, the teaching of understanding of conflict and peace and the facilitation of social independence, grass-roots movements are important to peace-building efforts. However, there is inadequate research on the efficacy of the strategies used by grassroots organization especially in informal settlements, on peace and cohesion. It is against this backdrop that this study was envisaged (Kristimanta, 2021).

\section{LITERATURE REVIEW}

There is no single strategy that suites peace and cohesion building in any community because of differences in situation (Flint \& Robinson, 2008). Intercommunity peace and cohesion requires sustainable engagement of different strategies and at all levels of society depending on a wide range of conditions and the perception of this condition among the actors (Flint \& Robinson, 2008, 
Diken\&Laustaen, 2009, Lederach\& Mansfield, 2020). According to Cantle (2018) a sustainable peace and intercommunity cohesion strategy should bridge the societal polarizing lines such as ethnicity, race, class and religion. A number of strategies have been used in various. Cantle(ibid) and Laderch (1997) advocates for economic prosperity, good governance, pursuit of human right, security, Education and training programs on conflict transformation and community initiatives that helps build local relationships.

Grassroots organizations use various strategies to build peace and intercommunity cohesion entirely depending on the needs of the communities or a reaction to specific events. Some grassroots organizations use various capacity building strategies to enhance peaceful coexistence among community members. Capacity building of communities means empowering communities in all spheres of life to enable them have control over various aspects of their lives (Connolly and York, 2002). Many grassroots organizations in the informal settlements use capacity building in form of economic empowerment such as poverty reduction to build peace and cohesion Informal-settlement communities have formed savings groups within the local communities.In Kathmandu , Nepal for example post conflict peace and cohesion projects integrates the women's savings and credit cooperatives because the SACCOs are prevalent and attract large number of members and therefore provide good stage for locally based peace and cohesion effort (Ramnarain, 2015). Apart from economic empowerment of women, the grassroots organizations also carry out activities such as roundtable peace talks, radio/TV talk shows, mediation and negotiation for peace, Street Dramas, peace rallies, peace training and production and dissemination of publications on the effect of conflict (Mawby, \&Applebaum, 2018; ADB, 2013).

Women engagement in various income-generating activities Microfinance and Water Supply and Sanitation Project have been very effective in bringing together diverse members of the community hence augmenting on the government effort at integration and cohesion. In India the community groups and leaders who live in informal settlements founded a national organization called the National Slum Dwellers Federation (NSDF), created in the mid-1970s. The NSDF mobilizes the urban poor to come together, articulate their concerns and find solutions to the problems they face. The aim of the federation is to address poverty through health, education and recreational activities and to strengthened community capacities, especially those of women, to fight demolition. They also tackle housing and infrastructure issues for the urban poor. NSDF organizes and mobilizes the urban poor to articulate their concerns and find solutions to the problems they face while Mahila Milan supports and trains women's collective efforts to administer and manage their community's resources. These initiatives and strategies are geared towards strengthening bonds between communities in the informal settlement through building their financial, capacities. (Mitlin, Patel \& Satterthwaite, 2001).The participation of members of the informal settlements in community driven development processes builds group identity and social solidarity resulting in community peace and cohesion.

Training of the women and Youth to empower them as agents of community peace and cohesion in the informal settlements is also a strategy used by grassroots organization (Algar-Faria, 2014). Members of grassroots organizations are educated on skills such as dispute management, positive interaction through dialogue, how to identify causes of overt and latent violence and how to respond and adapt them in their particular context. All this strategies are done through workshops, participation network or intergroup or interethnic exchange visit. In Kibra informal settlement in Nairobi, organizations such as Shalom Center for Conflict Resolution and Reconciliation train various groups on different aspect of conflict such as conflict mapping, conflict resolution, managing identitybased and natural resource-based conflicts; reconciliation and transforming the community for peace and cohesion (Erot, 2015). According to Maiese (2005), capacity building training assist participants to improve on communication, negotiation as well as problem solving skill that is important for peace building. Kamenshikov (2005) highlights on the activities undertaken by grassroots organization in response to violent conflict in the northern Caucasus in Russia. They work with the local Chechen community in the restoration of conflict devastated villages by organizing joint workshops of representatives of various ethnic communities. The problem-solving workshops, usually convened by third parties, bring representatives of conflicting groups together to seek solutions to shared difficulties. Workshop employed techniques like sensitivity training on the notion that this would advance communication and shared understanding between community members. The objectives of 
the workshop include: attitude change, the generation of innovative solutions, and improvement of intergroup relationships.

Grassroots organizations have also harnessed the use of art in community integration and cohesion. Shank and Lisa (2008) allude to the use of a variety of the arts, such as music, paintings, theatre dances, and storytelling as a strategies for community cohesion. This is because such activities offer an opportunity for members of the community a get together, and participate in cultural or arts based creative activity. The gatherings helped to developed mutual learning between diverse generations of residents in the community thus enriching and affirming a sense of identity and cohesion. Research carried out by McCabe, Phillimore and Ramsden (2011) reveals the development of voluntary amateur art groups for the low-income communities in England. These amateur theatre groups staged plays, drama workshops, training, and the development of group work skills. This provided the community with a more artistic means of expression and developed a strong sense of community. Participation in grassroots community art created an opportunity for meaningful social connection and cohesion and generation of economic income from membership subscriptions advertisements service and provision. According to Alcaraz (2018) El Valle informal settlement in Venezuela, is divided in terms of economic status, political beliefs and cultural diversity but these are defused during creative art activities. The public arts offer the community by inspiring personal development and expression through street art, graffiti, poetry, circus arts, video and radio production, music dance, and theatre and provides a substitute to violence.

A research carried out by Tahir (2015) and Silverman (2015) both showed that grassroots art wasused in post-conflict areas in Pakistan. Traditional and modern forms of arts such as drama, painting, Music and films among others were used to raise awareness and inspiring hope, rebuild trust and empathy and promoting tolerance in communities devastated by conflict. Grassroots art based peace and cohesion building have also been used by some countries in Africa. A research carried out in Rwanda by Mtukwa (2016) showed that grassroots art made use of theatre, music, dance and poetry to re-build their communities after the genocide. Grassroots art organizations such as Umuhanziw'uGrassroots Theatre and Reconciliation Association and Abiyunze United theatre use drama and Role-playing to depict connections between perpetrators and victims of the genocide and to develop a change of the community attitude towards conflict integration. Smith \&Webb (2011) assert that participation in art activities help to reintegrate people into their community and contribute towards coexistence and reconciliation. Similarly, Laderach (2005) observed that greater concentration of arts and art related organizations lead to higher participation of community members which improves the quality of life and the development of cohesion.

Grassroots organizations have also harnessed the local sports as a strategy for peace and cohesion(Cárdenas, 2013). According to Lindsey (2013) sports are commonly believed to create positive cohesive roles because divided communities are brought together through a shared sporting interest. Grassroots sport organization such as local community based sport clubs provide an opportunity for members of the community to participate and engage in a wider social network because they meet regularly to play, facilitate and watch sports. Lindsey and O'Gorman (2015) argue that sports as an art is advocated for as a tool to address cultural violence, engender reconciliation and aid rehabilitation primarily by building social networks and educating participants. A Participatory action research carried out by Fletcher and Meir (2017) showed that sports has been used in the United Kingdom to help develop interactions and understanding between people from diverse backgrounds. Cities in the Northern England such as Bradford, Oldham and Burnleys had suffered racialized tension between white majority and the minority ethnic communities which had culminated into a series of widespread riots and racial disturbances (Hassan \&Mitra, 2015). The research data was collected from participant of low social economic background in the ethnically segregated borough of Northwest England. The research concluded that the most effective way to build cohesion in a diverse background through sports is to allow ownership and participation of the community. The London local government has taken up the potential for promoting community cohesion through sport.

According to the mayor of London report (2018) community sport is advocated for and used as a strategy to improve social integration through new program sport unites. Community sport organizations such as Hounslow Sports Clubs and Osterley Sports Network have been used to bring the segregated communities together through the promotion of specific values discipline and hard 
work. According to report by Streetgames (2019), Newnham, the sixth most deprived district in England use sports activities to bring together youths from different communities and to enable them to forging strong, new friendships and creating a sense of pride and belonging within their communities. The aim is to use sport programs to assist migrant settlement and to increase community cohesion. Krasniqi and Krasniqi (2018) carried out a study on the role of sports particularly Open Fun Football Schools (OFFS) in promoting coexistence in Kosovo. The research revealed that a Danish organization known as Cross Cultures Project Association (CCPA) uses grassroots sports as a strategy for community cohesion and post conflict reconciliation. Kosovo had suffered conflict between Catholic Croats, Orthodox Serbs, and Muslim Bosniaks after the breakup of the former communist Yugoslavia that resulted in the breakup of the ethnic communities. Findings showed that OFFSs played a vital role by bridging the difference in the diverse ethnic backgrounds in Kosovo. This lead to social inclusion of Albanians and Serbs, and other communities and changed their initial attitudes toward one another. The OFFS works under a simple slogan of bringing people together and has the ability to engage a wide scope of relevant stakeholders like school children, the youth and adults across different ethnic and social divides to interact and build relationships through a shared love for football. This has helped generate social cohesion, strengthen relations between people and build community platforms for dialogue (Woodhouse, 2009).

Countries emerging from conflict like Liberia have also used football at the grassroots level to bring communities together for peace and reconciliation. A research carried out by Collison (2013) revealed that WestPoint the largest informal settlement in Monrovia have grassroots organized football games between community members to help bring youth together. Liberia has entire generation of children and young people who had either actively participated in the war or had experienced war or and therefore missed out in education and acquisition of other skills. Grassroots football help to bring young people together reconciles communities and promotes community peace and cohesion. A study by Cardenas (2013) showed that Sport for Development and Peace (SDP) Initiative for Sierra Leonean have also used grassroots soccer as a way to integrate conflicting communities. Grassroots sports groups such as Sport for Peace for Youth and Play31 (which got its name from the 31st article of the Convention on the Rights of the Child) have used football to address and stop violence between youths faced with religious and ethnic conflict and to facilitate community football tournaments focusing on reconciliation.

Some grassroots organizations have adapted security as a strategy to sustainable community peace and cohesion. As stated by Ayobami et al (2017) the failure of many governments to deliver suitable security for their citizens has led to the adoption of community-based crime preventions where citizens have had to make their own provisions to guarantee their right to freedom and personal security. These strategies entail communities coming together to gather resources to combat local crimes. According to Mitlin, Patel and Satterthwaite (2001), the reluctance of the government to go into informal settlement and to act on complaints led to the formation of community policing in Pune and Mumbai informal settlement in India. A research carried by Shah (2014) revealed that Community organizations such as Slum Dwellers Federation and Mahila Milan provide police services in the form of "police panchayats" to maintain law and order and resolve clashes before they heighten into violence or other crimes. In Mumbai the panchayats are staffed and run by voluntary community workers from the informal settlement. The community workers are drawn from the community irrespective of the caste. The Neighbourhood Watch Association (NWA) is a grassroots movement in UK aimed at making the communities safer and friendlier right across England and Wales. A research carried by Guido (2016) in the UK revealed that NWA were formed by neighbourhood residents to maintain an informal watch over each other's property. The goal of this grassroots initiative was to increase sense of security in the residential areas and bring neighbours together by carrying out training of citizens on rules and regulation of security, publish printouts and develop cooperation with the police and the state in order to create strong, friendly, cohesive communities. Similarly, grassroots organizations have been used to enhance security in low-income areas of the United States.

A research carried out by Sakala, Harvell and Thomson (2018) revealed that grassroots organization such as South Bronx Community Connections in the city of New York have projects aimed at helping troubled youth in the community. The grassroots organizations try to change the youth's behaviour through life skill training and provide psychological services such as counselling. This has greatly 
reduced violence and youth recidivism to crime and enhanced the local capacity. Reliance on neighbourhood residents for support and mobilization of resources has greatly increased community participation and solidarity. Grassroots organization security are still used in Africa because of ineffective security. A study carried out by AyobamiOjebuye, Onyeche and Oladapo (2016) on the effectiveness of community-based crime prevention (CBCP) in Ibadan, Nigeria showed that the shortage of proper security in the country has forced the governments to seek non-state security interventions in form of CBCP especially in the informal settlements. The prevalent grassroots organization security isin form of residential associations, community associations, or sometimes, property owners' associations. The community safety, low level of crime and peaceful coexistence is attributed to these CBCPs. The grassroots organization initiative generates a significant safe space to help communities identify and resolve problems, protect themselves from violence and injustice and to promote community peace and cohesion. Communities with security responsibility act cohesively therefore develop strong social network vital for peace building and community cohesion (Sampson, 2004). Sharkey, Torrats-Espinosa, and Takyar (2017) argue that urban areas with community organizations that aim at crime reduction and increased community well-being experienced greater reductions in violence strengthen community cohesion.

Grassroots organizations have also played a crucial role in disarmament, demobilization and reintegration (DDR) programs. Kaplan and Nussio (2018) carried out a survey of former combatants in Colombia and the reliability of e grassroots organization strategies in reintegrate ex-combatants into the community. The Colombian Agency for Reintegration (ACR) and with the help of grassroots integration strategy have demobilized ex-combatants from both right-wing paramilitary groups and left-wing guerrillas. The implementation of Grassroots interventions was envisioned to increase the level of confidence between communities and ex combatants through strategies such as dialogue, community project or cultural events. According to Derks, Rouw, and Briscoe (2011) and Kaplan and Nussio (2018) grassroots organizations such as The Peasant Workers Association of the Carare (ATCC) establish dialogued with armed groups to offer security assurances through a communitybased monitoring system to ensure the safety of the ex-combatants. The indigenous populations also employ communitarian-healing process to re-join ex-combatants, usually guerrilla members, with their families and communities. A research carried out by Schuberth (2017) revealed that Informal settlement in the Port of Prince in Haiti have resorted to the use of more community-focused armed violence reduction and prevention (AVRP) program instead of the DDR programs. According to a report by MINUSTAH (2007) the AVRP design interventions such as cash-for-work schemes and provision alternative means of income more suitable for Haiti's urban-armed groups. The outcome has been the fostering of trust through community participation hence reduction of the need of armaments and strengthening of community peace and cohesion.

Grassroots organization in form of Community-Driven Development (CDD) programs have been used to support post conflict societies. According to Boonyabancha (2005), there has been an increase in community level organizations within the informal settlements forming into citywide federations and national and international community groups for example Asian Coalition for Housing Rights (ACHR), Muhila Millan in India and The national federation of slum dwellers international. These organizations use community level saving to enhance community driven development in the urban informal settlements. Through the bonds that arise from shared management of finances, Community members develop trust for one another hence the development of peace and community cohesion.

A case study carried out in Thailand by Bhatkal and Lucci (2015) a network of grassroots organizations are involved in in the development and upgrading of Baan Mankong informal settlement in Thailand. The grassroots organization, being key actor in the development process, are responsible for finding land, negotiating tenure arrangements with landowners, designing housing projects, and implementing them. This has created a greater sense of ownership peace and community cohesion. An impact evaluation research carried out by Esenaliev et al (2018) that examined the magnitude CDD interventions on reinforcement of community cohesion revealed that CDD led to cooperation and built social networks among socially and ethnically diverse communities. The survey finding concluded that Project such as infrastructure, schools, hospitals, nutrition programs and business development provided basic services that eased the tensions within local communities and strengthened positive relationships. 
Fearon et al. (2009) randomized field experiment to evaluate the impact of a CDD project in northern Liberia revealed that community participation in the CDD projects led to increased cohesion and promotion of social reconciliation among the communities that were initially at war with each other. Similarly the Building Bridges to Peace program in Uganda initiated economic projects such as building of dams for increased community water accessibility, joint farming on land that was formerly inaccessible due to insecurity, and the joint rehabilitation of local marketplaces with the aim of building trust and economic contact between different ethnic groups with a history of violence. (Mercy Corps report 2016). Bayne and Vaux (2013) also argue that some community-driven development initiative are initiated mainly to support relationship building, trust and cooperation amongst populations. For example, in the aftermath of the Rwandan genocide, Oxfam supported a community-based development program in collaboration with local authorities and grassroots communities to aid in reconciliation. Community development project which also aim at poverty reduction are effective in building peace and cohesion within and outside the community because collaborative work enhances contact between people resulting in reduced tensions and creation of peace and sense of security (Taniguchi, 2012).

Walton (2010) also argues that providing job opportunity decreases strains and frustrations that stems from unemployment, advances people's economic condition, and allows for opportunity to interact, all of which promotes stability and community cohesion. Some grassroots organizations advance collaborative activities as a strategy to create peace and cohesion in the community. These activities include water projects, road construction or any other income generation project that employ people from all identity groups to reduce channels of conflict (Kubasu, 2008).Blum and Grangaard (2018) argue that such concerted projects helps to nurture positive attitudes among the antagonistic groups. Once they start working together, participants gradually move beyond anger bitterness, and resentment.

According to Putnam (2002) and Haider (2009) grassroots organizations also provide social services to resolve collective action problems when formal institutions are lacking. Raman (2012) carried out a case study of Orangi, a low-income settlement in the outcast of Karachi in Pakistan. Divided political loyalties emanating from varied ethnicities in Orangi made it the epicentre of ethnic and political violence. A grassroots organization project, Orangi Pilot Project (OPP), was aimed at building the environment and developing community cohesion in the process. The inclusion and participation of the citizens in building and financing of sewer lines created partnership and fostered good social networks and community cohesion in a volatile area. The research finding showed that the OPP has played a crucial role in bridging ethnic and political groups, and increasing interethnic engagement. Allowing citizen ownership of the service helped to reduce tension, built horizontal social cohesion and helped citizens to focus on reconstruction rather revenge (Ibid). Similarly, in a study conducted in Dhaka the capital city of Bangladesh by Granada, Haque, Joseph \& Pagans (2018) cited that there is a growing number of grassroots organizations that work hand in hand with NGO to provide services such as water, sanitation and education. This has not only provided health benefits but have also created a sense of citizenship and community cohesion in low-income areas of Gaza.

According to Haider (2009) the assumption behind community-led project for cohesion is that participation in common projects, such as service delivery, livelihood and community development projects facilitates interaction among formerly divided communities, change their perceptionsof the other and dispel negative myths. Grassroots organizations in the urban informal settlements have formed syndicates of waste pickers or recyclers because of the failure of Conventional waste management system in unplanned urban areas (Okot, 2012). A study carried out by Satterthwaite et al., (2011) revealed that Zabaleen community-based recycling system, a grassroots organization in Cairo offer services such of garbage collection to generate income for the youth and the women. By doing so, they make a significant contribution towards creation of employment and income among the urban poor. The organization also train members on skills for recovery and recycling, such as turning office paper into handmade craft paper and cards and rags into hand-loomed rugs, bags, and quilts, to generate income and support community health clinics and literacy and training programs. According to Pargal, Gilligan and Mainul (2000) repeated interaction by economic actors through collective action such as garbage collection helps in development of horizontal networks that strengthen trust and community cohesion. 
Haider (2009) argues that provision of services such as environmental management, health, infrastructure, education, livelihoods and employment generation through the formation of grassroots organizations fosters peace and cohesion across divides, and forms a foundation for peace restoration and reconciliatory processes. Grassroots organizations have also adopted community health work as a strategy for peace and community cohesion. This is because health care is one of the principal means by which members of a society express their commitment to each other's welfare, promote feelings of security and of belonging to a broad, inclusive group that respects people and meets their common needs (MacQueen, \& Santa Barbara, 2000). In Kenya, for example community primary health workers and volunteers in Mathare Informal settlement in Nairobi support peace-building efforts in communities where they work in the understanding that a health is determine by peace and cohesion (Njiru, 2019). As emphasized by Laderach (1997) progress towards more peaceful and cohesive relationships in a community requires multitrack actions at several levels, which may also include community primary health workers and volunteers. The World Health Organization (WHO) underscore health as a bridge for peace policy framework on the understanding that health care providers play a crucial role in the preservation and promotion of peace (Garber, 2002). According to the UN report (2011) service delivery that is done at grassroots, level is valuable especially for a country that is emerging from conflict because it creates an entry point for other functions such as protection and social cohesion and helps the war-affected population and to support reconstruction of the state and society.

Strategies used by grassroots organizations in enhancing community peace and cohesion in the urban informal settlement have shown that reinforcement of community peace and cohesion can be done with greater participation of community members. Strategies such as sports and community driven development play a great role in creating contact between members of grassroots organization. According to Pettigrew and Tropp (2006) contact reduces prejudice and stereotype that characterises urban informal settlement due to immigration people of diverse origin.

\section{MeTHOdOLOGY}

This study was anchored on the descriptive research design as it sought to investigate the influence of grassroots organizations in the creation of peace and community cohesion in Kibra informal settlement. The study used a descriptive research design because it provides a picture of the situation as it naturally happens. This design also examines variables in a single sample and to systematically measure, describe and interpret them(Bloomfield \& Fisher, 2019).Through this design, the study adopted both quantitative and qualitative approaches for purposes of analytical triangulation. The qualitative approaches were used to gain an understanding of underlying reasons, opinions, and motivations for the formation and role of grassroots organization in community cohesion through key informant in-depth interviews and Focus Group Discussions (FGDs). On the other hand, the quantitative approach was used to generate numerical data that was transformed into usable statistics for purpose of analysis.

The study was carried out in Kibrainformal settlement which spans across three locations namely Kibra, Sarang'ombe and LainiSaba, being part of the larger Kibra Sub County. The informal settlement is documented as the largest such settlement area in Africa (Mutisya\&Yarime, 2011; Bodewes, 2005). The study area was selected because it hostspeople from nearly all ethnic communities in Kenya. The area has also been put on the security watch list as one of the violence hotspots in the city of Nairobi, besides hosting quite a number of grassroots organizations (Mutisya\&Yarime, 2011).

The target population for this study comprised of household heads, members of grassroots organizations engaging in peace and community cohesion, national government administrators, specifically the chiefs and sub-chiefs and the Deputy County Commissioner, officials of National Cohesion and Integration Commission (NCIC) and the National Steering Committee on Peacebuilding and Conflict Management (NSCPCM) via the Sub-County Peace Committee in Kibra, all of whom amounted to 45,259 . It is from this population that a sample size of 384 was obtained using Cochran's formula: $\mathrm{n}=\frac{Z^{2} p q}{e^{2}}$, Where;

$\mathrm{n}$ is the sample size 
$\mathrm{Z}$, which is equal to 1.96 , is the standard normal deviation at a confidence level of $95 \%$

e which is equal to 0.05 , is the desired level of precision (i.e. the margin of error),

$\mathrm{p}$ which is equal to 0.5 , is the (estimated) proportion of the population which has the attribute in question,

$\mathrm{q}$ is $1-\mathrm{p}$

Using purposive, snowball, stratified and simple random sampling,the sample was proportionately distributed across the locations and grassroots organizations. The three locations namely Lindi, LainiSaba, Makina Olympic and Kibra were purposively sampled because they hosted the entire informal settlement and had witnessed recurrent violence and proliferation of grassroots organizations working on community peace and cohesion. Purposive sampling was further used to obtain key informants for interviews and leaders of grassroots organizations for the Focus Group Discussions (FGDs). Stratified simple random sampling was used to obtain heads of households on whom questionnaires were administered. Snowball sampling was used to obtain key informants especially national government administrators and respondents from the NCIC and the NSCPCM.

The resulting quantitative data was analysed by use of descriptive statistics with the help of SPSS version 25 while qualitative data was analysed using content analysis.

\section{Results}

The researcher used 338 questionnaires to collect data from the field. The data collection process was very successful as demonstrated by the fact that the researcher received backs all the issued questionnaires from the field. Out of the 338 questionnaires that were issued, 318, which represents 94\% response rate, were fully and appropriately answered by the respondents hence used in data analysis. Fincham (2008) advances that a response rate of at least $60 \%$ is sufficient to allow a researcher to proceed with data analysis. Consequently, given that the response rate from the data collection process was beyond the level advanced by Fincham, the researcher was able to proceed in using the collected data to carry out analyses of the different research questions.

\subsection{Strategies by Grassroots Organizations and Community Peace and Cohesion}

The study sought to establish some of the specific strategies used by grassroots organizations in Kibra informal settlements to enhance community peace and cohesion. Participant reported that the grassroots organizations used various strategies to help build community cohesion in the study area. In no order of preference, the respondents identified clean up exercises, sporting activities such as football, cultural festivals like cooking and drama festival, theatre arts such as dance and music, among others

Cumulatively, majority of the respondents $64 \%$ identified sports as a strategy used by grassroots organizations to build peace and cohesion while 33\% disagreed. The 33\% that disagreed argued that the sporting activities were not necessarily the sole effort of the grassroots organization, pointing out the sole effort of government and individual people. The 3\% that expressed neutrality was deemed insignificant in terms of altering the majority finding. The popularity and widespread use of sports by grassroots organizations was attributed to the fact that they attracted participants and audiences in huge droves and they transcended ethnic divisions. Grassroots organizations like Amani Kibra and Carolina for Kibra were found to have focused on assisting young people participate in conflict management and peacebuilding through sport, in the process learning the values of healthy competition and teamwork. Sports were found to promote cooperation and friendship among youths of diverse ethnic groups in Kibra. Grassroots organizations such as Carolina for Kibra and Amani Kibra were reported as having organized soccer competitions which attracted teams of diverse age groups and from different ethnic and religious backgrounds. One of the respondents had this to say on sports:

Grassroots organizations like Amani Kibra hold annual soccer tournaments for thousands of girls and boys from Kibra informal settlement. The main objectives of these tournaments are to bridge ethnic and gender divisions among the members of the community, teach about positive beneficial leadership, solidarity, and civic service. It is a rule and therefore mandatory that participating teams must reflect the 
ethnic diversity of Kibra. This creates rare opportunities for inter-ethnic teamwork and friendship and to keep the youth out of drugs and violence in the community. (FGD 3, Kibra 9/8/2020)

The study further established that during match intervals and after the matches, messages of peace, cohesion and reconciliation are exhibited through activities such as poems and music. The soccer tournament provides an opportunity for the youth to enhance their sporting talents and to shun violence. The sporting activity is used as a tool for community mobilization and to create awareness on community peace and cohesion. Community members get an opportunity to interact and socially network with others therefore fostering community cohesion. This finding is in line with O'Gorman (2015) argument that sports can be sued as a tool to address cultural violence, create reconciliation and build social network that enhance peace and cohesion in the community.

Theatre arts such as dance, music and graffiti were reported by $70 \%$ of the respondents as a major strategy used by grassroots organizations as a strategy for peace and cohesion, a view that was disputed by $23 \%$ of the respondents as a further $7 \%$ expressed neutrality to the use of the strategy. Grassroots organizations such as Kibra Hamlets and Kibra creative arts use arts and graffiti to pass messages of peace. The graffiti carried phrases, such as 'down with ethnicity, down with prejudice and peace wanted alive'. Graffiti was found to be an important medium to use as it has the power to resonate and 'speak' to the youth in Kibra. One of the participants in the focus group discussion had this to say about arts:

We write simple messaging like graffiti that speaks to the hearts and minds of the people of Kibra. As you might rightly guess, most of the residents here are not well educated and we figured out in our organization that complex messages might mean little in terms of achieving our objective. For us what they can see and participate in, they understand better and can relate with it in light of peace and cohesion Olympic (FGD 1,Kibra, 11/9/2020)

Grassroots organizations such as Pillars of Kibra theatre, Kibra Creative arts (KICA) and Kibra Hamlets use street theatre to pass massages of peace and reconciliation. Artistes gather and perform street music, dances, poetry, comedy and acrobatics that explore the theme of peace and community cohesion. Apart from entertainment, street theatres help the community to understand cohesion from a different perspective.

Cumulatively, $47 \%$ the respondents further highlighted that some organizations use cross-community visits as a means of reconciliation and to bring different communities together as another $47 \%$ disagreed on the use of community visits. In essence, the respondents were split down the middle as to the potency of cross community visits in furthering peace and cohesion as spearheaded by grassroots organizations. The $6 \%$ that expressed neutrality was considered significant as it could alter the findings either way on this particular item. One of the respondents from Kibra women of peace and fairness had this to say:

As women, we organize communal visit. Each one of us choses a friend from another community and conduct a visit. During the visit one is supposed to carry a staple food from their community as a gift to the friend. We share a meal with the peoplein her community and vice versa. This way we are able to learn more about their community and they are able to learn about our community when it is their turn to visit. (Olympic, FGD 2 11/9/2020)

This was also reiterated by members of the households who emphasised that such cross-communal visits were very important because they created good contact and allowed different ethnic groups to learn more about each other. The NCIC also advocates for inter-ethnic exchange visits as a strategy to promote peaceful coexistence, cohesion and integration within the county. Interethnic exchange improves multicultural understanding and empathy among members of diverse ethnicity living in the same country. A survey study conducted on eight ethnic groups in Iran by Hashemi, Yousofi and Reza (2017) revealed that the more porous the inter-ethnic regions are, the more tolerant the ethnic groups will be with each other. The inter-ethnic relationships pave the way for this social inclusion, which eventually creates community cohesion. This is synonymous with the contact theory, which 
argues that the most effective way to reduce prejudice and intergroup discrimination is by encouraging intergroup contact (Pettigrew \&Tropp, 2006).

The use of music and food festival events as a strategy to bring communities together was also reported by $46 \%$ of the respondents as a further $43 \%$ disagreed and $11 \%$ expressed neutrality. The neutral respondents were considered significant as they could easily change the majority finding if were they to drift and align with the minority. Songs were used to pass messages of peace, love and unity. They also conduct multicultural events such as food festivals where different communities present different cultural dishes from their communities. During the festivals a great deal of work is done on tolerance as well as gender based violence campaigns. The hope is that Cultural program may help foster appreciation of cultural diversity and the creation of intercultural understanding and tolerance. Interdenominational prayers have also been conducted especially between the Muslims and the Christians living in Kibra. The aim is to reduce tension between the members from the two religions. Food sharing is one of the most significant way of bringing people together. It can promote understanding, help one to familiarize with new cultures and get people to dialogue. Chapple-sokol (2013) argues that the food sharing which he refers to as culinary diplomacy can be used as an instrument to create cross-cultural understanding in the hopes of improving interactions and cooperation.

A research carried out by Dunbar (2017) revealed that the grassroots organization in Sri Lankan initiate peace education and promoted ethnic cohesion between the Sinhalase and Tamil community by inviting them to a community centre where they cook and eat together. The participants also bring traditional food as gifts for others. Giving gifts symbolizes the elements of brotherhood and sisterhood, friendship and solidarity. In Africa, many indigenous peace-building traditions emphasise the value of food sharing as a way to initiate social solidarity. Among the West African communities Kolanut was used as a cultural tool for connectivity and bonding (Tertsea\&Shaik, 2019). Communal eating increases a feeling of wellbeing and social bonding. The interaction also enables the diverse groups to develop a new positive experience with each other.

Economic empowerment was reported by $58 \%$ of the respondents as a strategy used to promote community peace and cohesion initiatives in Kibra informal settlements, a view that was disputed by $33 \%$ of the respondents. Many grassroots organizations were found to combine peace and community cohesion together with economic empowerment of members. In an effort to mitigate the effects of unemployment, most grassroots organizations were reported to have come up with regular programs and trainings to aid the unemployed in communities. The Mazingira Women Initiative for instance was reported as using waste papers and plastics collected during their community clean-ups to make briquette (charcoal) which were then sold to the community at a reasonable price compared to charcoal made from timber. They also recycling of cartons and plastic paper to make bags and shopping baskets and sell to the community. Grassroots organizations such as Kibra women for peace and fairness use group loans and saving to economically empower the members. Socio-economic benefits of group savings enhance cohesion because members of the group work together under common set of ethical norms, it is based on trust and constant contact breeds familiarity and interethnic understanding. Integration of savings in peace and cohesion projects have similarly been done in Nepal because they attract large number of members and therefore provide good stage for locally based peace and cohesion effort (Ramnarain, 2015).

Finally, joint economic ventures were reported by $55 \%$ of the respondents as a popular and very effective approach to enhancing cohesion among the different ethnic communities residing in the Kibra informal settlement, a view that was disputed by $33 \%$ as a further $12 \%$ expressed neutrality. A number of reasons were advanced by the majority respondents to explain the popularity of this approach. The first explanation was that most of the time, conflicts arose among the diverse ethnic groups due to their different political ideologies they subscribe to and their political affiliations. Beyond politics, they do not find it difficult to engage in economic activities hence the effectiveness of this approach. Secondly, joint economic activities are sure ways to promote economic wellbeing of individuals and their households especially in conflict prone zones. Through such activities, participants are able to augment their incomes. It therefore becomes impossible to turn down such activities despite the differences that individuals may have. Another way of looking at this finding is the fact that during times of conflict, there is a lot of group-think and mob psychology after which 
each individual is left to his or her own devices. Consequently, these individuals will be willing to come together, put aside their differences and join forces and engage in joint economic activities to, as already mentioned, enhance their economic statuses. As stated by Galster (2015) economic development promotes extensive opportunities for those within a society and lower levels of conflict.

From the open ended questions, the respondents identified the involvement of political actors in peace building and cohesion as strategy to mobilize the community towards peace and cohesion programs. It was reported that politicians provided the political will needed for the acceptability of the organizations programs by the masses over whom they have considerable influence. During an FGD meeting, a participant explained the importance of politicians thus:

The major cause of division in Kibra is economic deprivation and negative ethnicity. However, these issues are worsened by the political class especially during the campaigns. Our organization strongly roots for inclusion of politicians in peace and cohesion drives because of the immense influence they have on their supporters. By acknowledging and giving them a role to play, we increase the acceptability of our programmes among their followers and it also serves to highlight the fact that the leadership is fully supportive of our initiative. (FGD 2LainiSaba,26/9/20202)

The significance of including political actors in community peace and cohesion programming is largely informed by their influence. This finding was established to be in agreement with Castillejo (2016) argument that political actors provide the much-needed goodwill that rallies their constituents towards a common goal and purpose. Political actors help to broker the end of conflict by addressing the conflict drivers and fosters conflict reconciliation thus building a national consensus. This eventually creates a platform for grassroots organizations effort in community peace and cohesion.

Ideally, the various strategies identified above are not mutually exclusive. Rather, they complement each other so that the widest possible audiences are reached within a given period and the intended messages are effectively passed across in order to enhance cohesion and integration among the residents of Kibra informal settlement. In a nutshell therefore, it was found that generally, communal clean ups, sporting activities, performance arts theatres and the use of community based mainstream media were the most commonly used and most preferred strategies used by the grassroots.

\subsection{Observable Changes in Inter-group Cohesion since Formation of GROs}

A research question sought to establish the observable changes in terms of intergroup cohesion that could be directly attributed to the efforts of grassroots organizations.Cumulatively, $65 \%$ of the respondents indicated that there was greater inclusion of youth in various activities hence the reduction of youth idleness and youth violence. A further $28 \%$ disagreed that the youth had been included in peace activities as $7 \%$ expressed neutrality. Sporting activities and arts were found to be more attractive and very appealing to the youth and some adults beyond the youth bracket, hence they attracted many residents. Community based organizations such as Amani Kibra and Kibra Hamlets organize youth activities such as sports and theatre to provide an opening for the youth to identify and boost their talent and as an instrument for community mobilization. These activities attract youth from different age, gender, ethnic and religious backgrounds and has gained popularity as an annual event in the informal settlement. In the process, youth engagement became more visible and enhanced and this particular demographic has continued to own the peace and cohesion emanating from these programs and which they have participated to build. One of the respondents had this to say about sports and youth:

The beauty with sports is that they foster a sense of team work because you can't win alone unless it is something like board games. Football for example brings together teams comprising at least 22 players. So you can imagine sports will bring together the players and their supporters and the cooperation in there is used to stir peoples mind sets to see how they need each other. So for me, I must say I'm happy to say there are improved relations especially among the young people from all the ethnic communities because of these sporting activities. I encourage them and appeal for support in enhancing them to develop talent as well (FGD 2, Olympic 11/9/2020)

This was in sync with Woodhouse (2009) argument that sports help to generate social cohesion, strengthen relations between people and build community platforms for dialogue. Grassroots 
organizations such as Kibra Joy Initiative, Kibra Hamlets, Kibra youth ambassadors for peace and many others are mainly composed of the youths in the community. They engage the youth in what they call youth Conner activity where the youth discuss the challenges, they face in their community and how to resolve them. The youth leaders also train the members on peaceful coexistence. One of the respondent reported a reduction of criminal activities by the youths because of their involvement in constructive activities. Gunderson and Fazio (2014) argue that idleness create a sense of uselessness that can translate into increased crime drug abuse violence and conflict.

Another change observed and attributed to the work of grassroots organizations as reported by $63 \%$ of the respondents was detribalization of self-help groups in the informal settlement as an effective approach in cultivating intercommunal cohesion, with a further $31 \%$ expressing a contrary opinion. Some respondents observed that prior to the work of grassroots organizations, most self-help groups were formed along ethnic lines and were ethnically exclusive. Encouraging individuals from different ethnic backgrounds to form and join inclusive self-help groups is an approach that has over the years been taken by grassroots organizations to foster inter-communal cohesion. This approach has been successful and effective in achieving the intended objectives. The respondents also reported that the social economic welfares are now formed based on friendship and not ethnicity. All these transformations from ethnically exclusive groups to a more inclusive and ethnically diverse arrangements have not only enhanced cohesion among the different ethnic groups in Kibra but has also assisted in times of need and emergencies. These changes, it can be said, have been supplementary to the activities and programmes on peace and cohesion spearheaded by grassroots organizations. The considerable success of this strategy, can also be attributed to the fact that these self-help groups provide the members with opportunities to uplift one another economically through buying and sharing items such as household items, clothes and foodstuff among the members. Moreover, these groups enhance social relations among members because they find opportunities to share stories and experiences beyond the objectives of the groups.

Allport's Contact Theory (1954) argues that when people come into contact they learn more about each other and this reduces any prevailing prejudices and stereotypes. Forest and Kearn (2001) also argue that the level of community cohesion can be identified by the level of social interaction within the community or families, sense of belonging to a place and the willingness to assist others. The research finding shows that Kibra is endowed with social network groups that can be harnessed to help develop peace and cohesion in the region welfare practices based on cooperation and social support networks that respond to social need and promote community well-being welfare practices based on cooperation and social support networks that respond to social need and promote community well-being. Given that only a small percentage of the respondents agreed with the fact that the socio economic activities had been detribalized, others might still be of the opinion that the welfare groups were still operating along ethnic line.

Another observable change attributed to the activities of the grassroots organizations was the expansion of ethnically inclusive neighbourhoods as reported by $47 \%$ of the respondents. Instructively, a further $47 \%$ of the respondents disagreed that there was such a change. In essence, the two groups held diametrically opposed views in terms of the emergence of ethnically inclusive neighbourhood. The $6 \%$ that expressed neutrality were thus considered significant as they could tilt the finding either way depending on which they chose to align with. Some respondents reported that after 2007/2008 post elections violence in Kenya, many ethnic groups in Kibra moved and lived in residential areas according to their ethnic communities for security reasons. But through the efforts of grassroots organizations friends from different ethnic groups can now share residential areas. Stolle et al (2008) argues that geographical proximity creates an opportunity for interaction and weakens the negative impact of ethnic diversity on socia0l cohesion. The dissenting group pointed out that there still existed mistrust between ethnic groups and this worked against the cultivation of interethnic peace. These fears were partly attributed to the naming of some neighbourhoods using names that were perceived to come from certain ethnicities e.g. Karanja, Gatwekera, and Kisumu Ndogo which tended to project such areas as enclaves of the ethnicities associated with such names.

An important change advanced to have been observed and which was attributed to grassroots organizations as reported by $53 \%$ of the respondents was cleanliness of the environment. A further $38 \%$ disagreed that there was any noteworthy change in terms of the cleanliness of Kibra. The 
majority finding was explained as the effort of many grassroots organizations which were involved in the clean-up activities. Grassroots organizations such as Mazingira Women Initiative, Pillars of Kibra, Carolina for Kibra were found to mobilise community members to participate in the community clean-up activities. The organizations not only collected garbage but also recycled this garbage to earn an income for the group. Community participation in the clean-up exercises were reported to increase cooperation, an initial building block for enhancing trust between diverse communities living in the study area thus, mitigating tensions and conflict. According to Ellery and Ellery (2019) voluntary participation in programs such as environmental clean-ups enhance social network and helps to develop a sense of place. Moreover, such initiatives promote sustained interaction and long-term relationship that encourage peace and cohesion.

Finally, 58\% of respondents also attributed the significant reduction in electoral violence in 2013 and 2017 as compared to 2007/2008 general election to the presence of grassroots organizations working towards peace and community cohesion in Kibra. $34 \%$ of the respondents however disagreed that there was any significant reduction in electoral violence. The study established that most of the grassroots organization that have a component of peace and cohesion in their programs were formed after 2007/2008 post-election violence. Others that had been formed earlier had minimal peace and community cohesion programs as part of their objectives. Grassroots organizations such as Kibra Women for peace and fairness and Kibra youth ambassadors for peace among others conducted prevention of election violence training and peaceful coexistence in the community activities which helped a lot in the reduction of electoral violence. The grassroots organizations have also been engaged supportive post-conflict healing and community reconciliation through intercommunal dialogue, training workshops for the youth to develop skills to resolve conflicts without resorting to violence. The research can therefore conclude the proliferation of grassroots organization in Kibra informal settlement has led to changes that have been noted by the community members. The recurrent theme of the respondent is that the activities of the organizations have promoted peace and cohesive coexistence amongst communities from diverse ethnicity.

Other changes observed which were reported by the respondents included a reduction in ethnic prejudice and discrimination compared to the previous years when the grassroots organizations were not active. The respondents reported that the 'othering' connotations that residents of the informal settlement used to direct against people from other ethnic communities reduced drastically due to efforts of the grassroots organizations that encouraged members to shun such pronouncements. Increasingly, respondents noted that, people from different ethnic communities were being more open and more comfortable to the idea of living amidst other ethnic communities thus fostering community cohesion in the informal settlement. Notable decline in ethnic animosity among the different ethnic communities was also noted as a positive achievement of the activities of grassroots organizations. The respondents were also in agreement that, there is increased sense of belonging among the residents of the informal settlement. For instance, there is increased recognition of leadership positions in the grassroots organizations.

\subsection{Effectiveness of Grassroots Organizations in fostering Community Cohesion}

The study sought to find out how effective the grassroots organizations had been in fostering community peace and cohesion in Kibra informal settlement. The first statement sought to establish whether there was a reduction in incidents of intercommunal violence attributable to the activities of grassroots organizations. The study findings in this regard indicated that a majority of the respondents (51\%) held the view that grassroots organizations activities and programs had been effective in reducing incidents of intercommunal violence. A further $46 \%$ of the respondents disagreed while $8 \%$ were neutral. The neutral finding was considered significant has it could alter the majority finding.

This finding was explained by the fact that the various grassroots organizations operating in Kibra informal settlements had a reduction of inter-communal violence as one of their key target objectives. This is due to the fact that depending on the proportions or degree of disagreements between or among different ethnic tribes residing in Kibra, violence is one of the ever present hallmarks of such expressions of hostilities. The nature and degree of violence depend on the issue under contention among the warring factions. For instance, during electioneering periods, violence among different ethnic tribes become full-blown. This therefore justifies the prioritization of tackling violent expressions by grassroots organizations in Kibra. 
The second question set out to determine how effective grassroots organization were in cultivating community peace and cohesion by assessing the extent of sharing of communal social amenities. The results showed that cumulatively, 53\% of the respondents agreed that grassroots organizations had been effective in fostering sharing of communal social amenities in an effort to nurture intercommunal cohesion in Kibra. About $44 \%$ of the respondents disagreed, arguing that though there was sharing of social amenities, it could not be directly linked to efforts of grassroots organizations but rather an organic understanding of individual and collective rights coupled with enforcement by the government authorities. The common recreational facilities found in the informal include recreational facilities such as playing fields and social halls.

Other communal social amenities are those provided by the government such as hospitals and schools. Since they do not have much choice, residents of Kibra informal settlement, irrespective of their differences, are compelled to share the government-availed social amenities. However, recreational amenities can be subjected to discriminatory use depending on their location as well as numerical advantage of the dominant ethnic tribes where these amenities are located. Grassroots organizations' efforts in encouraging sharing of these amenities were found to be effective in enhancing communal cohesion in the informal settlement. This finding can be attributed to the view that sharing of these communities provide the different communities with the opportunities to interact freely and positively with one another thus enhancing the communal bonds. This is also in line with to Pettigrew and Tropp (2006) argument that repeated interaction by actors through collective action helps in development of horizontal networks that strengthen trust and lowers tension that creates conflict.

The third statement intended to evaluate the significance of a common language in fostering interethnic peace and harmony in Kibra informal settlement. The results demonstrate that nearly one third of the respondents, 33\%, strongly agreed that this approach to fostering cohesion was effective. Approximately $18 \%$ of the participants agree with this question statement while $3 \%$ of the respondents were not certain whether or not this strategy was effective in attaining the intended objective of enhancing inter-communal cohesion. A total of $45 \%$ of the survey participants responded negatively to this question with $21 \%$ of them disagreeing that the use of common language in public spaces/gatherings was effective in enhancing cohesion among the different ethnic tribes residing in the informal settlement of Kibra while the rest $24 \%$ strongly disagreed with this question statement.

Encouraging members from different ethnic backgrounds to use common languages in public forums was relatively effective in fostering inter-communal cohesion in the informal settlement. Slightly more than half of the participants responded positively to this question while a considerable proportion responded negatively to this question. This results can be attributed to the fact that in Kibra informal settlements, just like in other informal settlements in other urban centres in Kenya, the use of Swahili, and sometimes English, as a common language in public gatherings, is already an existing practice hence the little effect this approach had in fostering cohesion among different ethnic communities in Kibra informal settlement. Nonetheless, it is essential to note that the strategy made a difference however marginal it may be. Nordquist (2013) echoes that the use of common language should be incorporated in broader peace and development policies. This is because common language enable groups to communicate more easily with one another.

The researcher also sought to investigate whether joint communal security initiatives in Kibra informal settlement contributed to peace and ethnic cohesion. The study findings indicate that an aggregate of $61 \%$ of the respondents with $16 \%$ of them strongly agreeing that such initiatives throughout Kibra were effective in fostering cohesion among the different ethnic tribes and communities residing in the informal settlement while $45 \%$ of the positive responders simply agreed with the question statement. About $26 \%$ of the survey participants strongly disagreed that joint communal security initiatives were effective in fostering cohesion among the different ethnic tribes in Kibra informal settlement. Those who simply disagreed with this question statement were $16 \%$. The remaining $8 \%$ of the respondents were impartial.

The importance of safety and security of the residents of the informal settlement to a significant extent explains the findings of the analysis of the question on effectiveness of the joint security effort. The respondents acknowledged that there were ethnically oriented joint community securities in the past but these were dismantled by the government out of fear that they could be used during electioneering campaign to cause havoc. The National local administration the formed their own joint security that 
encompassed all peace and cohesions stakeholders such as the NGO, the government security officers the community members and the members of Grassroots organizations that deal with peace and cohesion in the community. They hold joint security meetings chaired by the chiefs of every location on a monthly basis to discuss matters about insecurity in the locations. The solutions to insecurity are tackled through community initiatives such as the NyumbaKumi (ten Houses) initiatives. The joint security initiatives have gone a long way to ensure the reduction in criminal activities in the informal settlement. The literature review revealed that a similar initiative was carried out in in Pune and Mumbai informal settlements. According to Mitlinet al. (2001) community policing through "Panchyatas" (community police) is done by the locals in Pune and Mumbai through grassroots organizations to increase security in these settlements. This is mainly due to the reluctance of government police to go into informal settlement or to act on security complaints.

Finally, the researcher sought to determine the importance of inter-communal marriages in the peace and cohesion. The results indicate that $10 \%$ of the survey participants strongly agreed that marriages among the different ethnic tribes and communities living in Kibra informal settlement encouraged cohesion in the community and was therefore effective in fostering inter-communal cohesion in the informal settlement. The proportion of respondents who agreed with this question statement was $21 \%$. At $38 \%$, majority of the respondents were neutral with regard to this question. About $16 \%$ of the respondents disagreed that increased inter-communal marriages had been effective in enhancing cohesion among the different communities living in Kibra and the rest 13\% strongly disagreed with this question statement.

Results of the analysis of the question on effectiveness of inter-communal marriages reveal sharply divided opinions among the respondents. Interesting in this analysis is the fact majority of the respondents were neutral which implies that from their point of view, they were not sure whether marriages among the different ethnic tribes residing in the informal settlement contributes directly or even significantly to cohesion among the different communities. Even more interesting is the revelation that the equivalence in the proportion of both positive and negative responders to this question. This goes to indicate that in as much as there were notable increased instances of intercommunal marriages among the different tribes residing in this informal settlement, it was difficult to substantiate the contribution of such instances to cohesion and integration in Kibra. This sharp division in opinion can be explained by the view that marriages do not, in most instances, happen for convenience purposes but people get into marriages with the people they fall in love with but not necessarily with an express intention to enhance good relationships and cohesion among their different communities or ethnic tribes.

\section{CONCLUSION}

Grassroots strategies for cohesion and peace building can attract at-risk populations onto programs where they can be offered other social services.Sports help to generate social cohesion, strengthen relations between people and build community platforms for dialogue. Grassroots organizations such as Kibra Joy Initiative, Kibra Hamlets, Kibra youth ambassadors for peace and many others are mainly composed of the youths in the community. There were conflicting opinions to what extend grassrootsinitiatives of peace building were effective, however, the study revealed existence of various strategies and the fact that they had some level of effectiveness. Youth engagement is more visible and enhanced and this particular demographic has continued to own the peace and cohesion emanating from these programs and which they have participated to build.There were notable increased instances of inter-communal marriages among the different tribes residing in the informal settlement, although it was difficult to substantiate the contribution of such instances to cohesion and integration in Kibra.Repeated interaction by actors through collective action helps in development of horizontal networks that strengthen trust and lowers tension that creates conflict.

\section{REFERENCES}

[1] Abegunde, A. A. (2009). Community based organisations in the sustainable development of rural areas of Atiba L.G.A., Oyo state. Journal of the Nigerian Institute of Town Planning, 17, pp. 1-14.

[2] Abegunde, A. A. (2009). The role of community based organisations in economic development in Nigeria: The case of Osogbo, Osun state, Nigeria. International NGO Journal, 4, pp. 236-252.

[3] Abegunde, A. A. (2010). A study on the impacts of communal conflicts on physical development of settlements in Southwestern Nigeria (Doctoral dissertation). Obafemi Awolowo University, Ile Ife. 
[4] Abrams, D. (2011). Wherein Lies Children's Intergroup Bias? Egocentrism, Social Understanding, and Social Projection. Child Development, 82(5), pp. 1579-1593.

[5] Abrams, D. (2010). Processes of prejudice: Theory, evidence and intervention: Equalities and Human Rights Commission (Research report 56). Retrieved from December 20, 2019 from https://www.equalityhumanrights.com/sites/default/files/research-report-56-processes-of-prejudicetheory-evidence-and-intervention.pdf

[6] Adan, M., \&Pkalya. R., (2006). The Concept Peace Committee. A Snapshot Analysis of the Concept Peace Committee in Relation to Peacebuilding Initiatives in Kenya. Nairobi: Practical Action.

[7] ADB (2013). Engagement in Fragile and Conflict-Affected Situations. The Role of Women in Peacebuilding in Nepal. Asian Development Bank Publication Stock No. ARM135756-2.

[8] Adler, P., \& Kwon, S., (2002). Social Capital: Prospects for a New Concept. The Academy of Management Review, 27(1), 17-40. Retrieved August 28, 2019, from http://www.jstor.org/stable/4134367

[9] Agee, J. (2009). Developing Qualitative Research Questions: A Reflective Process. International Journal of Qualitative Studies in Education, 22(4), pp. 431-447.

[10] Aiken, N. T. (2008). Post-Conflict Peacebuilding and the Politics of Identity: Insights for Restoration and Reconciliation in Transitional Justice. Peace Research: The Canadian Journal of Peace and Conflict Studies 40(2), pp. 9-38.

[11] Aiken, N. T. (2010). Learning to Live Together: Transitional Justice and Intergroup Reconciliation in Northern Ireland. International Journal of Transitional Justice, 4(2), pp. 166-188.

[12] Åkerdahl, H. (2013). Nationally Initiated Local Peace Committees. On the Structure and Functioning of the Nakuru Peace Committees in Kenya.

[13] Al Ramiah, A. \&Hewstone, M. (2013). Intergroup Contact as a Tool for Reducing, Resolving, and Preventing Intergroup Conflict Evidence, Limitations, and Potential. The American Psychologist. 68(7), pp. 527-542.

[14] Algar-Faria, G. (2014). Social Movement Theory and Resistance Groups: The Global Justice Movement and Occupy Wall Street. Global Discourse, 4(2-3), pp. 203-204.

[15] Allport, G. W. (1954). The Nature of Prejudice. Cambridge, Mass. Addison-Wesley Publication Company.

[16] Anderson Margaret and Taylor Howard (2003) Sociology: Understanding a Diverse Society. 3d ed. Belmont, CA: Wadsworth. 2003. 736 pages. \$95.95. Sociology.

[17] Arias-Granada, Y., Haque, S. S., Joseph, G. \& Yanez-Pagans, M. (2018). Water and Sanitation in Dhaka Slums: Access, Quality, and Informality in Service Provision. Policy Research Working Paper Series 8552, the World Bank.

[18] Arya, N. (2004). Peace Through Health I: Development and Use of a Working Model. Medicine, Conflict and Survival, 20(3), pp. 242-257.

[19] Arya, N. (2004). Peace through Health II: A Framework for Medical Student Education. Medicine, Conflict and Survival, 20(3), pp. 258-262.

[20] Ashby, P. (2002). Child Combatants: A Soldier's Perspective. The Lancet, 360(9350), pp. 11-12.

[21] Asian Development Bank. (2013). The Role of Women in Peacebuilding in Nepal.

[22] Australian Bureau of Statistics (2003). Annual Report, 2002-03. Retrieved April 18, 2020 from https://www.abs.gov.au/AUSSTATS/abs@.nsf/allprimarymainfeatures/28D45FB6109EEEB2CA2570AC 00112308 ?opendocument

[23] Autesserre, S. (2017). International Peacebuilding and Local Success: Assumptions and Effectiveness. International Studies Review, 19(1), pp. 114-132.

[24] Barman, D. \& Vadrevu, L. (2016). How is Perceived Community Cohesion and Membership in Community Groups Associated with Children's Dietary Adequacy in Disadvantaged Communities? A Case of the Indian Sundarbans. BMC Health Services Research, 16(7, 622).

[25] Baú, V. (2016). Citizen Engagement in Peacebuilding: A Communication for Development Approach to Rebuilding Peace from the Bottom-up. Progress in Development Studies, 16(4), pp. 348-360.

[26] Bayne, S. \& Vaux, T., (2013). Integrated development and peacebuilding programming: Design, monitoring and evaluation. London, England: DfID.

[27] Beider, H., (2011). Community Cohesion: The Views of White Working-Class Communities. York, UK: JRF.

[28] Bercovitch, J., Kremenyuk, V. \&Zartman, W. I. (2009). The Sage Handbook of Conflict Resolution. Sage Publications London. 
Strategies Employed by Grassroots Organizations in Anchoring Community Peace and Cohesion in Kibra Informal Urban Settlements in Nairobi, Kenya

[29] Berger-Schmitt, R. (2002). Considering Social Cohesion in Quality of Life Assessments: Concept and Measurement. Social Indicators Research, 58(1/3), 403-428. Retrieved August 28, 2018, from http://www.jstor.org/stable/27527016

[30] Binder, J., Zagefka, H., Brown, R., Funke, F., Kessler, T., Mummendey, A., Maquil, A., Demoulin, S., \&Leyens, J. P., (2009). Does Contact Reduce Prejudice or Does Prejudice Reduce Contact? A Longitudinal Test of the Contact Hypothesis Among Majority And Minority Groups In Three European Countries. Journal of Personality and Social Psychology, 96(4), pp. 843-856.

[31] Bishnu, R. \&Upreti, B. R., (2014). Peace and Post Conflict Reconstruction in Nepal: A bird's-eye view 1.

[32] Bloomfield, J., \& Fisher, M. J. (2019). Quantitative research design. Journal of the Australasian Rehabilitation Nurses Association, 22(2), 27-30.

[33] Blum, A., \&Grangaard, R. (2018). Collaborative Design in Peacebuilding: Lessons from the Central African Republic. US Institute of Peace.

[34] Bodewes, C. (2005). Parish Transformation in Urban Slums: Voices of Kibra, Kenya. Nairobi: Paulines Publications Africa.

[35] Bornman, E. (2016). Intergroup Contact Experience and Frequency as Predictors of Cross-racial Attitudes. Journal of Psychology in Africa, 26(1), pp. 63-69.

[36] Brown, J. D. (2001). Using Surveys in Language Programs. Cambridge, England: Cambridge University Press.

[37] Brown, J. D. (2009). Open-Response Items in Questionnaires. In: Heigham J., Croker R.A. (eds). Qualitative Research in Applied Linguistics. Palgrave Macmillan, London.

[38] Burton, J. (1990). Conflict: Human Needs Theory Center for Conflict Analysis and Resolution George Mason University, Virginia, USA. The Macmillan Press Ltd.

[39] Büscher, K. (2018). African Cities and Violent Conflict: The Urban Dimension of Conflict and Post Conflict Dynamics in Central and Eastern Africa. Journal of Eastern African Studies, 12(2), pp. 193-210.

[40] Byrne, S., Thiessen, C., Fissuh, E. Irvin, C. \&Hawranik, M. (2008). Economic Assistance, Development and Peacebuilding: The Role of the IFI and EU Peace II Fund in Northern Ireland. Civil Wars, 10(2), pp. 106-124.

[41] Cantle, T. (2008). Community Cohesion: A New Framework for Race and Diversity. Basingstoke: Palgrave Macmillan

[42] Cantle, T. (2012). Interculturalism: For the Era of Globalisation, Cohesion and Diversity. Political Insight, 3(3), 38-41.

[43] Cárdenas, A. (2013). Peace Building Through Sport? An Introduction to Sport for Development and Peace. Journal of Conflictology. 4(1), pp. 24-33.

[44] Cárdenas, A., (2016). Sport and Peace-Building in Divided Societies: A Case Study on Colombia and Northern Ireland. Peace and Conflict Studies, 23(2, 4).Retrieved December, 2, 2019 from https://nsuworks.nova.edu/pcs/vol23/iss2/4

[45] Castejello C. (2016). Political parties and peace-building: The Forgotten Stakeholder in Peace Processes.

[46] Chapple-Sokol, S. (2013). Culinary Diplomacy: Breaking Bread to Win Hearts and Minds. The Hague Journal of Diplomacy, 8(2), pp. 161-183.

[47] Flick, U. (2018). An introduction to qualitative research. London: Sage Publications

[48] Flint, J., \& Robinson, D. (Eds.). (2008). Community cohesion in crisis? New dimensions of diversity and difference. Policy Press.

[49] Kristimanta, P. A. (2021). Grass-Roots Post-conflict Peacebuilding: A Case Study of Mosintuwu Women's School in Poso District, Central Sulawesi, Indonesia. In Decolonising Conflicts, Security, Peace, Gender, Environment and Development in the Anthropocene (pp. 569-590). Springer, Cham.

[50] Nganje, F. (2021). Local Peace Committees and Grassroots Peacebuilding in Africa. In The State of Peacebuilding in Africa (pp. 123-139). Palgrave Macmillan, Cham.

Citation: Christine JumaAgaya, Godfrey Ungaya, Emily Okuto. "Strategies Employed by Grassroots Organizations in Anchoring Community Peace and Cohesion in Kibra Informal Urban Settlements in Nairobi, Kenya” International Journal of Humanities Social Sciences and Education (IJHSSE), vol 8, no. 4, 2021, pp. 239-255. doi: https://doi.org/10.20431/2349-0381.0804020.

Copyright: (C) 2021 Authors. This is an open-access article distributed under the terms of the Creative Commons Attribution License, which permits unrestricted use, distribution, and reproduction in any medium, provided the original author and source are credited. 